\title{
Organic Carbon and Particle-Size Distribution in the Littoral Bottom Sediments of the Laspi Bay (the Black Sea)
}

\author{
N. A. Orekhova*, E. I. Ovsyany \\ Marine Hydrophysical Institute of RAS, Sevastopol, Russian Federation \\ *natalia.orekhova@mhi-ras.ru
}

Purpose. The work is aimed at estimating the organic carbon abundance in the bottom sediments of the littoral zone in connection with the state of macrozoobenthos in the Sevastopol region coastal waters with different levels of the anthropogenic pressure (by the example of the Laspi Bay).

Methods and Results. The samples were taken in the dynamically active coastal-shelf zone (up to the depths $\sim 20 \mathrm{~m}$ ) of the Laspi Bay in September, 2017. Two samples were taken during the $103^{\text {rd }}$ cruise of R/V "Professor Vodyanitsky" (September, 2018). The geochemical composition of bottom sediments was investigated. The bottom sediments of natural humidity were analyzed in accordance with the requirements of the regulatory documents. In the sediments containing the aleurite fraction in the central part of the Laspi Bay (station 4), the organic carbon content $\left(\mathrm{C}_{\text {org }}\right)$ increased its natural course up to $0.46 \%$, but did not exceed its maximum values characteristic of the similar lithological sediments in the shallow-water part of the Crimea Southern Coast $(1.14 \%)$. In the deep part of the bay occupied with the aleurite-pelitic silt, the $\mathrm{C}_{\text {org }}$ content exceeded $2 \%$. Absence of the $\mathrm{C}_{\text {org }}$ accumulation within the depths under study is conditioned primarily by the grain-size composition of the bottom sediments, the hydrodynamic factor and the morphometric features of this coastal site. Presence of a small portion of the aleurite-pelitic fraction in the bottom sediments also does not promote the organic carbon accumulation. Thus, spatial distribution of the carbon organic and inorganic forms is conditioned by the features of the matters' lateral migration, which, in its turn, is governed by dependence of the bottom sediments' chemical and dispersion structure upon the environmental morphodynamic conditions.

Conclusions. The littoral sediments were found to be characterized by a low organic content $\left(\mathrm{C}_{\mathrm{org}}=\right.$ $=0.16 \%)$ not exceeding the geochemical background values of the surface bottom sediments in the Black Sea shelf zones. At present, the organic matter accumulation is determined by the features of the environmental morphodynamic conditions (transition of fine particles to the deep zones) and by the dispersed composition of the bottom sediments.

Keywords: bottom sediment, organic carbon, zoobenthos, the Laspi Bay, the Black Sea.

Acknowledgements: the investigation was carried out within the framework of theme No. 08272019-0004 and the RFBR project No. 18-05-80028 Hazardous phenomena "Studies and scaling of water dynamics and biogeochemical processes in development of oxygen deficit and sulfidic conditions in coastal regions of Crimea and Kerch Strait”.

For citation: Orekhova, N.A. and Ovsyany, E.I., 2020. Organic Carbon and Particle-Size Distribution in the Littoral Bottom Sediments of the Laspi Bay (the Black Sea). Physical Oceanography, [e-journal] 27(3), pp. 266-277. doi:10.22449/1573-160X-2020-3-266-277

DOI: $10.22449 / 1573-160 X-2020-3-266-277$

(C) N. A. Orekhova, E. I. Ovsyany, 2020

(C) Physical Oceanography, 2020

Organic matter (OM) of sea bottom sediments is a key ecological indicator determined the trophic basis for the development of benthic communities and their habitat conditions. At the same time, the excessive input and, as a result, accumulation of organic carbon $\left(\mathrm{C}_{\text {org }}\right)$ negatively affect both the benthic community (leading to a decrease in the number and species diversity) and the conditions of its habitat. Previously, the effect of OM accumulation in bottom sediments (BS) on 
the benthic community $[1,2]$ and changes in the characteristics of the marine environment of Sevastopol coastal waters with an increase in anthropogenic load [3-5] were considered.

The Laspi Bay (the Black Sea) has long been regarded as one of the cleanest sea areas in the Sevastopol region [6]. However, the increased anthropogenic load, especially in the last decade, in the absence of a systematic approach to rational use and appropriate environmental protection measures, has led to a significant change in the bay ecosystem characteristics, particularly in bottom biocenoses ${ }^{1}$. Under the conditions of increased organic pollution input into the coastal ecosystems, structural changes in the zoobenthos of the Laspi Bay loose soils are noted [7].

The main purpose of this work is to estimate the organic carbon content in the bottom sediments of the littoral zone in the modern period in connection with the macro-zoobenthos state in the Sevastopol region coastal waters with different levels of anthropogenic load (for example, the Laspi Bay).

\section{Materials and methods of the study}

The materials were sampled in September 2017 in a dynamically active coastal-shelf zone (down to $20 \mathrm{~m}$ depths) of the Laspi Bay when the Department of Benthos Ecology of A. O. Kovalevsky Institute of Biology of the Southern Seas RAS performed a benthic survey. BS samples $(0-5 \mathrm{~cm}$ layer) were taken with a hand sampler during light diving operations. Two samples were taken during expeditionary work on the $103^{\text {rd }}$ cruise of R/V Professor Vodyanitsky (September 2018). The scheme of sampling stations is shown in Fig. 1, the information on the material collection and general characteristics of the bay bottom sediments - in Table. 1. The geochemical composition of BS was investigated. Bottom sediment sampling and preparation were carried out in accordance with GOST 17.1.5.01-80, ISO 5667-12:1995 and ISO 5667-19: 2001.

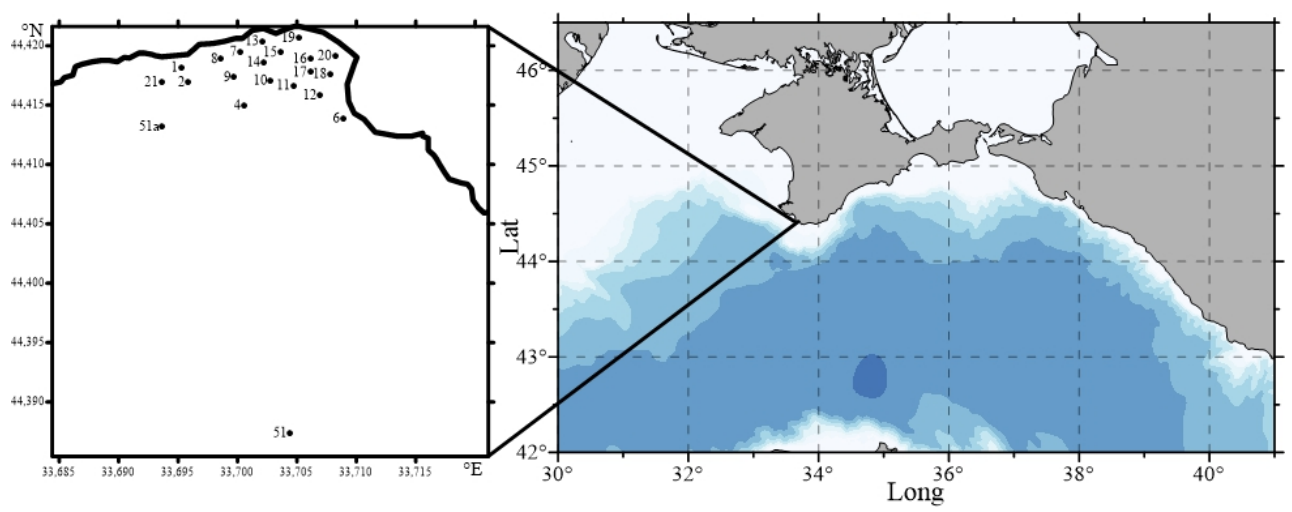

F i g. 1. Scheme of the bottom sediment sampling stations in the Laspi Bay

${ }^{1}$ Zaskokov, G., 2017. [Laspi, Koktebel and Bolshaya Yalta are Leading in the Discharge of Untreated Sewage into the Sea]. Noviy Den [New Day], September 27. [online] Available at: https://newdaynews.ru/crimea/615881.html [Accessed: 14 May 2020] (in Russian). 


\section{Overall description of the surface layer $(0-5 \mathrm{~cm})$ characteristics of the Laspi Bay bottom sediments}

\begin{tabular}{|c|c|c|c|c|c|}
\hline \multirow{2}{*}{$\begin{array}{l}\text { Station } \\
\text { number }\end{array}$} & \multirow{2}{*}{ Depth, m } & \multicolumn{2}{|c|}{ Coordinates } & \multirow{2}{*}{$\begin{array}{l}\text { Humidity, } \\
\%\end{array}$} & \multirow{2}{*}{$\begin{array}{l}\text { Characteristics of the grain-size composition of } \\
\text { bottom sediments }\end{array}$} \\
\hline & & $\mathrm{N}$ & $\mathrm{E}$ & & \\
\hline & 2 & 3 & 4 & 5 & 6 \\
\hline 1 & 14,5 & $44^{\circ} 25^{\prime} 50^{\prime \prime}$ & $33^{\circ} 41^{\prime} 40^{\prime \prime}$ & 29.4 & $\begin{array}{l}\text { dark-grey sand (91)* with aleurite (8) and gravel } \\
\text { admixture (1) }\end{array}$ \\
\hline 2 & 18,0 & $44^{\circ} 25^{\prime} 01^{\prime \prime}$ & $33^{\circ} 41^{\prime} 45^{\prime \prime}$ & 23.3 & $\begin{array}{l}\text { coarse-grained sand (52) with gravel (47) and } \\
\text { aleurite admixture (1) }\end{array}$ \\
\hline 4 & 28,0 & $44^{\circ} 24^{\prime} 54^{\prime \prime}$ & $33^{\circ} 42^{\prime} 02^{\prime \prime}$ & 52.0 & sand (53) with aleurite (46) and gravel admixture (1) \\
\hline 6 & 13,0 & $44^{\circ} 24^{\prime} 50^{\prime \prime}$ & $33^{\circ} 42^{\prime} 32^{\prime \prime}$ & 6.8 & stone gravel (99) with sand admixture (1) \\
\hline 7 & 10,0 & $44^{\circ} 25^{\prime} 12^{\prime \prime}$ & $33^{\circ} 41^{\prime} 58^{\prime \prime}$ & 26.1 & dark-grey fine-grained sand (95) with aleurite (5) \\
\hline 8 & 13,0 & $44^{\circ} 25^{\prime} 08^{\prime \prime}$ & $33^{\circ} 41^{\prime} 55^{\prime \prime}$ & 31.4 & $\begin{array}{l}\text { dark-grey fine-grained sand (87) with aleurite } \\
\text { (12) and shell gravel admixture (1) }\end{array}$ \\
\hline 9 & 21,0 & $44^{\circ} 25^{\prime} 03^{\prime \prime}$ & $33^{\circ} 41^{\prime} 59^{\prime \prime}$ & 26.3 & $\begin{array}{l}\text { dark-grey sand (57) with aleurite (42) and shell } \\
\text { gravel admixture (1) }\end{array}$ \\
\hline 10 & 14,0 & $44^{\circ} 25^{\prime} 01,5^{\prime \prime}$ & "334ㄴ' $10^{\prime \prime}$ & 27.6 & $\begin{array}{l}\text { dark-grey sand (75) with aleurite (28) and shell } \\
\text { gravel admixture (3) }\end{array}$ \\
\hline 11 & 14,0 & $44^{\circ} 25^{\prime} 00^{\prime \prime}$ & $33^{\circ} 42^{\prime} 17^{\prime \prime}$ & 27.7 & dark-grey fine-grained sand (75) with aleurite (25) \\
\hline 12 & 15,0 & $44^{\circ} 24^{\prime} 57^{\prime \prime}$ & $33^{\circ} 42^{\prime} 25^{\prime \prime}$ & 25.1 & $\begin{array}{l}\text { dark-grey fine-grained sand (80) with aleurite } \\
\text { (16) and shell gravel admixture (4) }\end{array}$ \\
\hline 13 & 6,0 & $44^{\circ} 25^{\prime} 14^{\prime \prime}$ & $33^{\circ} 42^{\prime} 08^{\prime \prime}$ & 21.6 & sand (98) with gravel (1) and aleurite (1) admixture \\
\hline 14 & 12,0 & $44^{\circ} 25^{\prime} 07^{\prime \prime}$ & $33^{\circ} 42^{\prime} 08^{\prime \prime}$ & 21.4 & sand (98) with gravel (1) and aleurite (1) admixture \\
\hline 15 & 9,0 & $44^{\circ} 25^{\prime} 10^{\prime \prime}$ & $33^{\circ} 42^{\prime} 13^{\prime \prime}$ & 22.9 & $\begin{array}{l}\text { dark-grey medium-grained sand (98) with } \\
\text { aleurite admixture ( } 2 \text { ) }\end{array}$ \\
\hline 16 & 8,0 & $44^{\circ} 25^{\prime} 08^{\prime \prime}$ & $33^{\circ} 42^{\prime} 21^{\prime \prime}$ & 22.5 & $\begin{array}{l}\text { dark-grey fine-grained sand (86) with aleurite } \\
\text { (13) and gravel admixture (1) }\end{array}$ \\
\hline 17 & 10,0 & $44^{\circ} 25^{\prime} 04^{\prime \prime}$ & $33^{\circ} 42^{\prime} 22^{\prime \prime}$ & 27.4 & $\begin{array}{l}\text { dark-grey fine-grained sand (64) with aleurite } \\
\text { (35) and gravel admixture (1) }\end{array}$ \\
\hline 18 & 9,0 & $44^{\circ} 25^{\prime} 04^{\prime \prime}$ & $33^{\circ} 42^{\prime} 28^{\prime \prime}$ & 21.2 & $\begin{array}{l}\text { dark-grey coarse-grained sand (84) with gravel } \\
\text { (15) and aleurite admixture (1) }\end{array}$ \\
\hline 19 & 4,0 & $44^{\circ} 25^{\prime} 15^{\prime \prime}$ & $33^{\circ} 42^{\prime} 19^{\prime \prime}$ & 25.0 & $\begin{array}{l}\text { dark-grey medium-grained sand (99) with } \\
\text { aleurite admixture (1) }\end{array}$ \\
\hline 20 & 5,5 & $44^{\circ} 25^{\prime} 09^{\prime \prime}$ & $33^{\circ} 42^{\prime} 30^{\prime \prime}$ & 23.1 & $\begin{array}{l}\text { dark-grey medium-grained sand (92) with gravel } \\
\text { (7) and aleurite admixture (1) }\end{array}$ \\
\hline 21 & 17,0 & $44^{\circ} 25^{\prime} 01^{\prime \prime}$ & $33^{\circ} 41^{\prime} 37^{\prime \prime}$ & 19.0 & gravel (66) with sand (33) and aleurite admixture (1) \\
\hline
\end{tabular}

* Percentage of a fraction are given in parenthesis. 
Natural humidity of sediments was analyzed according to the requirements of regulatory documents.

Grain-size analysis was carried out using the standard method in accordance with GOST 12536-2014 and ISO 11277:1998, taking into account the recommendations from V.P. Petelin work ${ }^{2}$ and the UNEP ${ }^{3}$ manual. The aleurite-pelitic fraction $(\leq 0.063 \mathrm{~mm})$ was separated by wet sieving technique.

The coarse-grained fractions $(>0.063 \mathrm{~mm}$ ) were separated by a sieving method after drying. The classification of marine sediments by size fractions is presented according to A.P. Lisitsyn ${ }^{4}$ with clarifications and detailed characteristics of grainsize composition in relation to coastal sediments ${ }^{5}$. The sediment name is given by the prevailing fraction, then the remaining components are given in descending order with an indication of their percentage.

The sediment moisture content was determined according to GOST R ISO 11465-2011, the inorganic carbon content (carbonate content) - by the weightvolume method after the decomposition of sediment carbonates with hydrochloric acid according to ISO 10693-2001, taking into account the methodological recommendations of UNEP ${ }^{3}$ manual; the concentration of organic carbon - by the spectrophotometric method after the oxidation of organic sediment substances with a sulfochromic mixture according to GOST 26213-91 and ISO 14235-1998.

To ensure the assessment of the analysis reliability, the state standard sample of BS was used: the accuracy of the analysis results was assessed using the standard sample of pelagic sediment with certified organic carbon content $\mathrm{C}_{\text {org }} 0.34 \%$.

Grain-size composition of the Laspi Bay BS

The Laspi Bay is located in the western part of the Southern Coast of Crimea and is bounded by Sarych and Aya Capes; it belongs to open water areas. The depths at the bay entrance are $60 \mathrm{~m}$, in the central part - $40 \mathrm{~m}$ with a decrease towards the coastline. The bay coast is an abrasion scarp of about 10-12 m height, composed of the Taurida Series rocks. This scarp is covered from above by Quaternary deposits represented by blocks, boulders, gravel and crushed stone of the Upper Jurassic limestones, sandstones and aleurolites [8, p. 152].

BS samples from the coastal zone bounded by $20-\mathrm{m}$ isobath were studied: exactly at these depths the main wave processing of sedimentary material, followed by its sorting at different distances from the coastline, is carried out. Bottom sediments of the area under study are mainly represented by high-carbonate psammitic sediments, sometimes with inclusions of stone and shell gravel material.

\footnotetext{
Russian).

${ }^{3}$ UNEP, 1995. Manual for the Geochemical Analyses of Marine Sediments and Suspended Particulate Matter. Reference Methods for Marine Pollution Studies, No. 63. 74 p. Available at: http://wedocs.unep.org/bitstream/handle/20.500.11822/1632/63eng.pdf?sequence=1\&isAllowed=y.

${ }^{4}$ Lisitsyn, A.P., 1966. Processes of Modern Sedimentation in the Bering Sea. Moscow: Nauka, 574 p. (in Russian).

${ }^{5}$ Nevesskiy, E.N., 1967. Sedimentation Processes in the Sea Coastal Zone. Moscow: Nauka, 255 p. (in Russian).
}

${ }^{2}$ Petelin, V.P., 1967. Grain-Size Analysis of Marine Bottom Sediments. Moscow: Nauka, 128 p. (in 
The selected samples of psammitic sediments are characterized mainly by fine and coarse-grained fractions $(0.5-0.1 \mathrm{~mm})$ with an admixture of shell and stone pebbles. To a lesser extent, they contain a coarse-aleurite fraction (0.1-0.05 mm) and least of all - fine aleurite and pelitic material $(0.01-0.005 \mathrm{~mm})$. Only at two stations (stations 6 and 21) the sediments with predominantly gravel (>10-2 mm) material were observed (Table 1, Fig. 2). Gravel fractions are represented by Jurassic limestones and biogenic material (shell limestone).

The BS autochthonous components are the products of biogenic sedimentation, namely, shell limestone and shell detritus formed as a result of wave processing [9, p. 65].

As can be seen from the grain-size analysis results (Table 1, Fig. 2), the main BS fraction is dark grey medium and fine grained sands, while the part of fine fractions (aleurite and pelite) does not exceed $1.5 \%$. The size and shape of detritus indicate its formation in an active hydrodynamic medium. It is obvious that the features of the water hydrodynamics [10] are the main factor in the formation of BS fractional composition in the bay. High dynamic activity of the waters facilitates the removal of finely dispersed material beyond 20-meter isobath (Fig. 3). On the basis of the zonal differentiation presented in [11], the investigated bottom section of refers to the zone of intense gravity drift (up to $300 \mathrm{~m}$ depths).

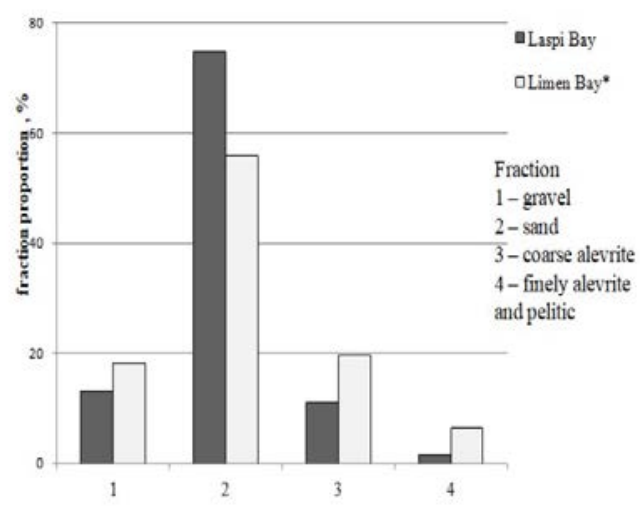

F i g. 2. Grain-size composition of the bottom sediments in the Laspi Bay (according to the data of 2017-2018) and in the Limen Bay (according to the data of 2012 [12])

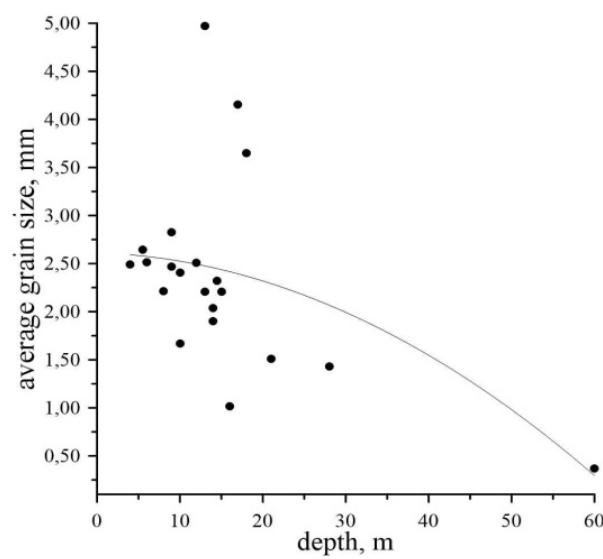

F i g. 3. Change of a particle average size of the Laspi Bay bottom sediments with the station depth

When comparing the BS grain-size structure of the studied water area and in the Limen Bay, which are in similar climatic conditions, one can note differences in the fractional composition (Fig. 2) both in the nature of the distribution of fractions and in their ratio. These differences are due to local features of geological and geomorphological environment, as well as abrasion, hydrodynamics and hydrobiology processes.

Organic carbon and BS carbon content

Total organic carbon content in the sea bottom sediments is one of the main characteristics in the study of geochemical aspects of sedimentation processes. In coastal waters exposed to anthropogenic impact, $\mathrm{C}_{\text {org }}$ content in the $\mathrm{BS}$ is one of 
the main geochemical indicators that characterize the marine ecosystem state [9, p. 67].

The results of the performed studies on the organic and inorganic carbon content in Laspi Bay in 2017 are given in Table. 2 and Fig. 4. Table 2 also presents information for other coastal areas of Crimea. As can be seen from Table 1 and 2, $\mathrm{C}_{\text {org }}$ content in the bay averages $0.16 \%$ for psammitic sediments and varies within the limits typical for geochemical background of surface bottom sediments of the Black Sea shelf zones; for shell rock $-0.66 \%{ }^{6}$. In the studied BS, which are mainly represented by sandy varieties enriched with carbonates $\left(\mathrm{CaCO}_{3} \geq 80\right.$ $90 \%$ ), the organic carbon content does not exceed $0.25 \%$. The maximum values of carbonate content in the Sarych Cape area (station 21) are associated with wave accumulation of shell and stone gravel. These values are comparable with the previously obtained results for the entire bay $-0.49 \%[6,14]$. They are of the same order of magnitude with the carbonate content in other open waters of the Crimean coastal shelf (Table 2).

In the aleurite sediments of the Laspi Bay central part (station 4) $\mathrm{C}_{\text {org }}$ content expectedly increases to $0.46 \%$ but does not exceed the maximum value $(1.14 \%)$, typical for lithologically similar sediments of the Southern Coast of Crimea coastal shallow water (Table 2). In the seaward part of the bay, occupied by aleurite-pelitic silts (Fig. 1, station 51), $\mathrm{C}_{\text {org }}$ content is more than $2 \%$. The absence of $\mathrm{C}_{\text {org }}$ accumulation within the studied depths is primarily due to BS grain size composition, hydrodynamic factor [10] and morphometric features of this coastal area (it is located in the zone of intense transportation of finely dispersed material into the seaward part [11]). The presence of aleurite-pelitic fraction in BS in an insignificant proportion (Fig. 2) also does not contribute to $C_{\text {org }}$ accumulation. Thus, the spatial distribution of carbon organic and inorganic forms of the Laspi Bay changes with depth (Figs. 4, 5) and is determined by the features of lateral migration of matter, caused by the dependence of the chemical and dispersion structure of BS on the environment morphodynamic conditions.

Comparative analysis of previous and obtained results indicates that over the past 20 years average organic carbon content in the Laspi Bay BS increased from 0.16 to $0.80 \%$, but significant changes in $\mathrm{C}_{\text {org }}$ concentration were absent. Currently, $\mathrm{C}_{\text {org }}$ content in the Laspi Bay BS is of the same order of magnitude as the data obtained in [6] (Table 2).

It should be taken into account that the presence of a cold methane degassing discharge zone in the studied area $[8,15]$ does not exclude the possibility of organic matter local accumulations: around the site of the gas jets outlet micro-oases of life, in which biogenic organic matter is formed during the process of bacterial chemosynthesis with the participation of methane, are formed. Organic matter synthesized by methanotrophic microorganisms becomes a trophic basis for the development of benthic organism communities.

\footnotetext{
${ }^{6}$ Mitropol'skiy, A.Yu., Bezborodov, A.A. and Ovsyany, E.I., 1982. Geochemistry of the Black Sea. Kiev: Naukova Dumka, 144 p. (in Russian).
} 
Organic matter $\left(\mathrm{C}_{\text {org }}\right)$, inorganic carbon $\left(\mathrm{CaCO}_{3}\right)$ and water $(\mathrm{W})$ content in the bottom sediments of some regions of the Crimea shelf (the Black Sea) based on the data from different sources

\begin{tabular}{|c|c|c|c|c|c|c|c|c|}
\hline \multirow[b]{2}{*}{ Region } & \multirow{2}{*}{ 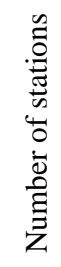 } & \multicolumn{2}{|c|}{ Corg, \% } & \multicolumn{2}{|c|}{$\mathrm{CaCO}_{3}, \%$} & \multicolumn{2}{|c|}{$\mathrm{W}, \%$} & \multirow[b]{2}{*}{ Data source } \\
\hline & & 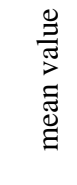 & $\begin{array}{l}\text { 茄 } \\
\text { ت्ञ }\end{array}$ & $\begin{array}{l}\stackrel{\Xi}{\Xi} \\
\stackrel{\widetilde{\pi}}{\geq} \\
\text { चี } \\
\stackrel{\Xi}{\Xi}\end{array}$ & $\begin{array}{l}\text { 足 } \\
\text { 馬 }\end{array}$ & 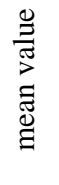 & 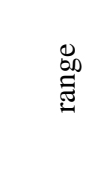 & \\
\hline the Laspi Bay & 20 & 0.16 & $0.09-0.46$ & 72.3 & 33.5-98.0 & 25 & $7-52$ & present study \\
\hline the Laspi Bay & 10 & 0.80 & $0.48-1.11$ & - & - & 34 & $25-48$ & [3] \\
\hline $\begin{array}{l}\text { the } \\
\text { Limen Bay }\end{array}$ & 12 & 0.51 & $0.23-1.08$ & 38.8 & $20.1-47.7$ & 27 & $13-55$ & [6] \\
\hline $\begin{array}{l}\text { Southern Coast of } \\
\text { Crimea }\end{array}$ & 26 & 0.50 & $0.16-1.14$ & - & $2.4-30.1$ & 27 & $20-30$ & [9] \\
\hline the Kalamita Bay & 20 & 0.37 & $0.23-0.60$ & 47.6 & 19.6-97.0 & 41 & $25-62$ & {$[12]$} \\
\hline the Kerch Strait & 73 & 1.40 & $0.12-5.02$ & 23.6 & $2.4-91.7$ & 71 & 23-169 & [13] \\
\hline
\end{tabular}

On the basis of indirect data, the authors of [8] speak about the possible local accumulation of organic matter in the zones of bubbly methane release under aerobic conditions. They think that in the methane chemosynthesis processes about $30 \%$ of the gas is processed into biogenic organic matter by archaea. However, there are no actual data on $\mathrm{C}_{\text {org }}$ content in the bacterial mats of the bay, which makes relevant additional research in the Laspi Bay. Earlier it was found that in the Black Sea littoral sediments in the Tarkhankut Cape area in summer, when the maximum bacterial biomass is reached, $\mathrm{C}_{\text {org }}$ content is more than $15 \%$ [16] but the mechanism of methane formation in this case differs from that observed in the Laspi Bay.

At the same time, one should not exclude an increase in the pollutants inflow with an anthropogenic load increase. The Laspi Bay coast every year becomes more and more attractive for recreation, and this is accompanied by the growth of human's activity and the development of public recreation complexes. At the same time, the state of the communal infrastructure does not adequately protect the marine environment from pollution ${ }^{7}$. According to our estimate, at least 25 tons of organic matter are annually inflow to the bay with wastewater.

7 Zaskokov, G., 2017. Laspi, Koktebel and Bolshaya Yalta are Leading in the Discharge of Untreated Sewage into the Sea. Noviy Den [New Day], September 27. [online] Available at: https://newdaynews.ru/crimea/615881.html [Accessed: 14 May 2020] (in Russian); Pisanko, Yu., 2019. What is Left Behind? Slava Sevastopolya, October 03. [online] Available at: https://slavasev.ru/2019/10/03/chto-ostavili-posle-sebya/ [Accessed: 14 May 2020] (in Russian). 

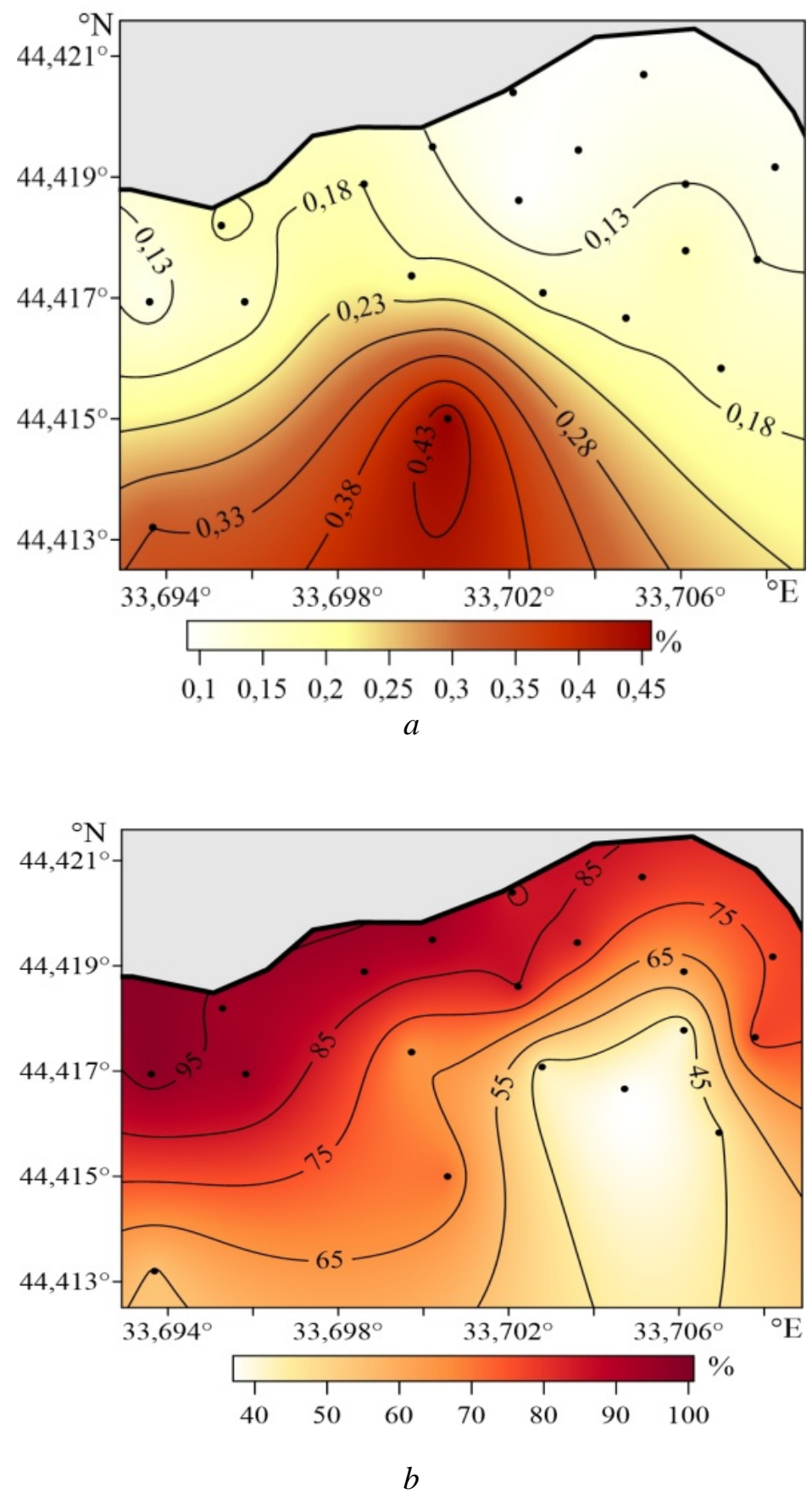

F i g. 4. Spatial distribution of organic and inorganic carbon in the bottom sediments of the Laspi Bay coastal part according to the results of the studies in 2017: $a-\mathrm{C}_{\text {org }}, \% ; b-\mathrm{CaCO}_{3}, \%$ 


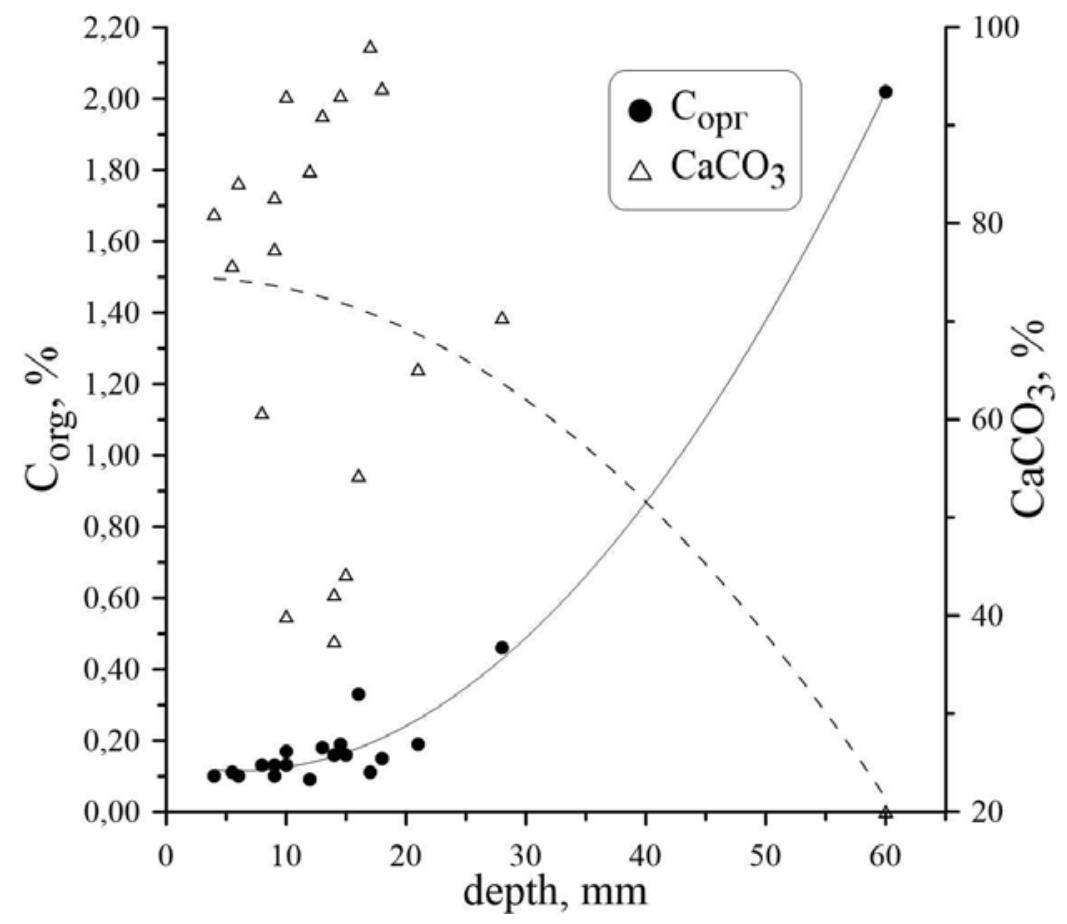

F i g. 5. Variation of the carbon content with the station depth

The water area under study is also used as a mussel plantation for aquaculture cultivation. Rather noticeable ecological impact of this plantation on the water area, which is expressed in the input and accumulation of OM in the BS in the area of its location, should be noted. In local areas of mariculture development, the variation in the composition and structure of a number of benthic invertebrate species populations are noted. In this case, siltation and contamination of BS occurs. Thus, according to work ${ }^{8}$, a mussel plantation of $500 \mathrm{~m}^{2}$ area with 2500 collectors releases 1.2 tons of bio-precipitate per year. In the future, the abundance of organic matter is inevitable as a result of the increased anthropogenic pressure on investigated area in the absence of a systematic approach and environmental protection. The changes in the structure of benthic community associated with a tendency to an increase in the marine environment pollution have already been identified, and the state of the bay ecosystem is alarming [7, 17]. The possibility of the bay BS pollution with organic matter is also indicated by the maximum level of abundance of heterotrophic and oil-oxidizing bacteria [18].

For further assessment of the bottom sediments state and $\mathrm{C}_{\text {org }}$ accumulation, the studied bay area should be expanded (to $\geq 60 \mathrm{~m}$ depths) to cover the entire grain-size variability of sediments, including silty soils, since the seaward part of the bay occupied by aleurite-pelitic silts has not been studied. In connection with the bay recreational zone development, an equally important task is to monitor the organic matter input with municipal wastewater. The role of methanotrophy in

8 Murina, V.V., ed., 1989. Biology of Cultivating Mussels. Kiev: Naukova Dumka, 99 p. (in Russian). 
the OM input to the bay BS should be assessed by analyzing carbon in bacterial mats. The assessment of mariculture ecological impact at significant expansion of fish-breeding areas for growing mussels and oysters is also required.

\section{Conclusion}

According to obtained data, it was revealed that BS of the Laspi Bay littoral zone, limited by the $20-\mathrm{m}$ isobath, are predominantly high-carbonate psammitic sediments, sometimes with inclusions of stone and shell gravel material. Sands are mainly represented by fine and coarse-grained fractions with an admixture of shell and stone pebbles, to a lesser extent by coarse-aleurite fraction and the smallest portion is fine-aleurite and pelitic material.

The main factors affecting the organic carbon accumulation in the BS of the Laspi Bay coastal zone are hydrodynamic and lithodynamic processes, as well as anthropogenic contributions. The study results indicate that there is currently noticeable $\mathrm{C}_{\text {org }}$ accumulation in the BS of the bay littoral zone (down to $\sim 20 \mathrm{~m}$ depth) are absent, despite the presence of pollution sources. The observed accumulation level is determined by the peculiarities of the environment morphodynamic conditions (move of fine fractions into submerged zones) and the dispersed composition of BS.

\section{REFERENCES}

1. Petrov, A.N., 2000. Responses of the Black Sea Macrobenthic Communities upon Organic Enrichment Impact of Bottom Sediments. Ecology of the Sea = Ekologiya Morya, (51), pp. 45-51 (in Russian).

2. Zaika, V.E., Konovalov, S.K. and Sergeeva, N.G., 2011. The Events of Local and Seasonal Hypoxia at the Bottom of the Sevastopol Bays and Their Influence on Macro-Benthos. Marine Ekological Journal = Morskoj Ehkologicheskij Zhurnal, 10(3), pp. 15-25 (in Russian).

3. Moiseenko, O.G. and Orekhova, N.A., 2011. Investigation of the Mechanism of the Long-Term Evolution of the Carbon Cycle in the Ecosystem of the Sevastopol Bay. Physical Oceanography, 21(2), pp. 142-152. https://doi.org/10.1007/s11110011-9111-9

4. Orekhova, N.A., Ovsyany, E.I., Gurov, K.I. and Popov, M.A., 2018. Organic Matter and Grain-Size Distribution of the Modern Bottom Sediments in the Balaklava Bay (the Black Sea). Physical Oceanography, 25(6), pp. 479-488. doi:10.22449/1573160X-2018-6-479-488

5. Romanov, A.S., Orekhova, N.A., Ignatyeva, O.G., Konovalov, S.K. and Ovsyany, E.I., 2007. Influence of Physico-Chemical Characteristics of the Bottom Sediments on the Trace Elements' Distribution by the Example of Sevastopol Bays (Black Sea). Ecology of the Sea = Ekologiya Morya, (73), pp. 85-90 (in Russian).

6. Mironov, O.G., Kiryukhina, L.N. and Divavin, I.A., 1992. [Sanitary-Biological Research in the Black Sea]. Saint Petersburg: Gidrometeoizdat, 115 p. (in Russian).

7. Revkov, N.K. and Nikolaenko, T.V., 2002. Biodiversity of Zoobenthos in the Coastal Zone of the Southern Coast of Crimea (Laspi Bay Area). Russian Journal of Marine Biology, 28(3), pp. 151-162. https://doi.org/10.1023/A:1016879418490 
8. Lysenko, V.I. and Shik, N.V., 2013. Contemporary Carbonates Formation Processes Associated with Hydrocarbons Degassing in the Underwater Part of the Laspi Bay Beach Zone (Southern Coast of Crimea). Space and Time, 2, pp. 151168 (in Russian).

9. Ovsyany, E.I. and Gurov, K.I., 2016. Research of Organic Carbon and Carbonate Content in the Bottom Sediments of the Crimean Southern Coast Shelf. Physical Oceanography, (1), pp. 60-70. doi:10.22449/1573-160X-2016-1-60-70

10. Atsikhovskaya, Zh.M. and Chekmenyova, N.I., 2002. Water Dynamic Activity Estimation in the Laspi Bay Area (the Black Sea). Ecology of the Sea = Ekologiya Morya, (59), pp. 5-8 (in Russian).

11. Gozhik, P.F. and Baysarovich, I.M., 1990. [Geological Model of the Laspinsky Canyon of the Crimean Continental Mountainside]. Dopovidi Akademii Nauk Ukrainskoi RSR, Seriya B: Geologichni Khimichni ta Biologichni Nauki, (7), pp. 8897 (in Russian).

12. Gurov, K.I., Ovsyany, E.I., Kotel'yanets, E.A. and Konovalov, S.K., 2014. Geochemical Characteristics of Bottom Sediments in the Kalamita Bay Water Area in the Black Sea. Morskoy Gidrofizicheskiy Zhurnal, (5), pp. 69-80 (in Russian).

13. Ovsyanyi, E.I., Konovalov, S.K., Mitropol’skii, A.Yu. and Kotel'yanets, E.A., 2015. Organic Carbon and Carbonates in the Recent Bottom Sediments of the Kerch Strait. Geochemistry International, 53(12), pp. 1123-1133. https://doi.org/10.1134/S0016702915120071

14. Kiryukhina, L.N., 1992. [Physico-Chemical Characteristics of Zernov Phylophora Field, Kalamitsky Gulf and the Crimean Shelf Bottom Sediments]. In: G.G. Polikarpov, ed., 1992. Molismologiya Chernogo Morya [Black Sea Molismology]. Kiev: Naukova Dumka, pp. 222-230 (in Russian).

15. Malakhova, T.V., Kanapatskii, T.A., Egorov, V.N., Malakhova, L.V., Artemov, Yu.G., Evtushenko, D.B., Gulin, S.B. and Pimenov, N.V., 2015. Microbial Processes and Genesis of Methane Gas Jets in the Coastal Areas of the Crimean Peninsula. Microbiology, 84(6), $\quad$ pp. https://doi.org/10.1134/S0026261715060053

16. Konovalov, S., Orekhova, N., Gurov, K., Myslina, M., Kanapatskiy, T. and Pimenov, N., 2017. Dynamics in Coastal Biogeochemistry near Methane Seeps. In: E. Özhan, ed., 2017. Proceedings of the Thirteenth International MEDCOAST Congress on Coastal and Marine Sciences, Engineering, Managements and Conservation, MEDCOAST 17, 31 October - 04 November 2017, Mellieha, Malta. Dalyan, Mugla, Turkey: MEDCOAST, Mediterranean Coastal Foundation, Vol. 2, pp. 1111-1119.

17. Milchakova, N.A., Mironova, N.V. and Ryabogina, V.G., 2011. [Marine Plant Resources]. In: V.N. Eremeev, A.V. Gaevskaya, G.E. Shulman and Ju.A. Zagorodnyaya, eds., 2011. Biological Resources of the Black Sea and Sea of Azov. Sevastopol: ECOSI-Hydrophysics. Chapter 4, pp. 117-139 (in Russian).

18. Doroshenko, Yu.V. and Burdiyan, N.V., 2016. Microbiological Characteristics of the Sediments of the Crimean shelf. In: A.V. Gaevskaya, ed., 2016. Marine Biological Research: Achievements and Perspectives: in 3 vol.: Proceedings of AllRussian Scientific-Practical Conference with International Participation dedicated to the 145th anniversary of Sevastopol Biological Station (Sevastopol, 19-24 September, 2016). Sevastopol: ECOSI-Gidrofizika, Vol. 3, pp. 81-83 (in Russian). 
About the authors:

Natalia A. Orekhova - Leading Research Associate, Head of Marine Biogeochemistry Department, Marine Hydrophysical Institute of RAS (2, Kapitanskaya Str., Sevastopol, 299011, Russian Federation), Ph. D. (Geogr.), ORCID ID: 0000-0002-1387-970X, ResearcherID: I-17552017; Scopus Author ID: 35784884700, natalia.orekhova@mhi-ras.ru

Evgeniy I. Ovsyany - Research Associate, Marine Hydrophysical Institute of RAS (2 Kapitanskaya St., Sevastopol, 299011, Russian Federation), ORCID ID: 0000-0002-6093-5102; Scopus Author ID: 6506585957

Contribution of the co-authors:

Natalia A. Orekhova - data processing, formulation of the main direction of the work, goals and conclusions; work with article materials

Evgeniy I. Ovsyany - material processing, chemical analysis, preparation of primary materials

The authors have read and approved the final manuscript.

The authors declare that they have no conflict of interest. 